\title{
Aplikasi Citra Landsat untuk Pemetaan Daerah Rawan Longsor di Kabupaten Bandung
}

\author{
Regina Febryzha Sawitri ${ }^{*}$, Dzulfiqar Baco Azhar ${ }^{1}$, Risa Ulfiyana ${ }^{1}$, Toto Karsius Karo-Karo² \\ 1 Jurusan Teknik Geofisika, Universitas Lampung, Jl. Prof. Dr. Ir. Soemantri Brojonegoro, No.1, Gedong Meneng, Kec. Rajabasa, \\ Kota Bandar Lampung, Lampung 35141 \\ ${ }^{2}$ Program Studi Teknik Pengelolaan dan Pemeliharaan Infrastruktur Sipil, Universitas Gadjah Mada, Bulaksumur, Caturtunggal, \\ Kec. Depok, Kabupaten Sleman, Daerah Istimewa Yogyakarta 55281
}

Dikirim:

26 September 2020

Direvisi:

9 November 2021

Diterima:

14 November 2021

Email Korespondensi:

reginafebryzha11@gmail.com

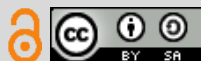

\begin{abstract}
Abstrak: Tanah longsor adalah gerakan tanah yang disebabkan oleh faktor alami dan non alami. Faktor alami dipengaruhi oleh struktur geologi daerah, jenis batuan, kemiringan lereng, dan intensitas curah hujan. Sedangkan faktor non alami bersifat dinamis yaitu penggunaan lahan dan infrastruktur. Metode penginderaan jauh dengan citra satelit dapat digunakan untuk memetakan kawan rawan longsor. Citra satelit merupakan hasil perekaman satelit yang menggambarkan objek di permukaan bumi. Citra satelit terdiri dari beberapa band dengan panjang gelombang tertentu. Komposit band pada citra digunakan untuk mempertajam objek untuk mempermudah klasifikasi tutupan lahan. Pemetaan zonasi area rawan longsor di Kabupaten Bandung menggunakan metode pembobotan dan skoring. Pembobotan dan skoring dilakukan pada semua parameter yang menyebabkan longsor yaitu struktur geologi, jenis batuan, curah hujan, kemiringan lereng, infrastruktur, dan tutupan lahan hasil pengolahan citra satelit. Hasil yang didapat menunjukkan potensi tanah longsor di Kabupaten Bandung didominasi kategori sedang sampai tinggi. Pemetaan kawasan rawan longsor sangat diperlukan sebagai langkah mitigasi untuk mengurangi dampak yang diakibatkan oleh bencana tanah longsor.
\end{abstract}

Kata kunci: tanah longsor, citra satelit, pemetaan, Kabupaten Bandung, gerakan tanah

\begin{abstract}
Landslides are land movements caused by natural and non-natural factors. Natural factors are influenced by the geological structure of the area, rock type, slope, and rainfall intensity. Meanwhile, non-natural factors are dynamic, namely land use and infrastructure. Remote sensing methods with satellite imagery can be used to map landslide-prone friends. Satellite images are the results of satellite recordings that describe objects on the earth's surface. The Satellite image consists of several bands with a certain wavelength. Composite bands in the image are used to sharpen objects to simplify land cover classification. Zoning mapping of landslide-prone areas in Bandung Regency using weighting and scoring methods. Weighting and scoring are carried out on all parameters that cause landslides, namely geological structure, rock type, rainfall, slope, infrastructure, and land cover resulting from satellite image processing. The results obtained show that the potential for landslides in Bandung Regency is dominated by moderate to high categories. Mapping of landslide-prone areas is needed as a mitigation measure to reduce the impact caused by landslides.

Keywords: landslides, satellite imagery, mapping, Bandung Regency, ground movement
\end{abstract}

\section{PENDAHULUAN}

Kabupaten Bandung terletak pada $107^{\circ} 14^{\prime}$ $107^{\circ} 56^{\prime}$ BT dan $6^{\circ} 49^{\prime}-7^{\circ} 18^{\prime}$ LS. Kabupaten Bandung merupakan daerah dataran tinggi dengan kemiringan lereng berkisar di antara $0-8 \%, 8-15 \%$, hingga di atas $45 \%$. Sebagian besar wilayah Kabupaten Bandung berada di antara perbukitan dan pegunungan. Berdasarkan letak geografisnya tersebut Kabupaten Bandung merupakan daerah yang termasuk dalam daerah rawan bencana tanah longsor, bahkan Kabupaten Bandung masuk dalam zona merah terkait dengan bencana tanah longsor melihat dari mayoritas daerah yang ada merupakan daerah perbukitan dan pegunungan. Sebagai contoh yang terjadi pada tanggal 16 Februari 2020 terjadi longsor di Kabupaten Bandung.

Tanah longsor adalah gerakan tanah yang disebabkan oleh faktor alami dan non alami. Faktor alami dipengaruhi oleh struktur geologi daerah, jenis batuan, kemiringan lereng, dan intensitas curah hujan. Sedangkan faktor non alami bersifat dinamis yaitu penggunaan lahan dan infrastruktur
(Zakaria, 2010; Wafa dkk., 2016; Wang dkk., 2017). Parameter yang digunakan untuk mengklasifikasi daerah rawan longsor terdiri dari aspek alami dan non alami. Untuk mendapatkan zonasi daerah rawan longsor di Kabupaten Bandung dilakukan metode skoring dan pembobotan dari parameterparameter yang menjadi faktor terjadinya tanah longsor. Perkembangan Sistem Informasi Geografis (SIG) dapat digunakan untuk upaya mitigasi, karena SIG memberikan informasi data geospasial dan sistem analisis keruangan yang akurat (Kurniawan, 2010; Akgun dkk., 2012).

Maksud penelitian adalah untuk penyusunan peta risiko bencana tanah longsor dengan aplikasi citra Landsat dan mengetahui daerah mana saja yang termasuk ke dalam daerah risiko bencana longsor Kabupaten Bandung. Pemetaan zona rawan longsor dapat dihitung berdasarkan integrasi spasial dari parameter-parameter yang mempengaruhi dan memicu longsor (Khosiah \& Ariani, 2017). Untuk mendapatkan parameter yang dibutuhkan dapat menggunakan metode pengindera- 
an jauh berdasarkan pengolahan citra Landsat (Erlansari dkk., 2020). Pengolahan ini dapat menghasilkan zonasi kawasan rawan tanah longsor berdasarkan parameter yang disebabkan oleh faktor alami dan non alami yang menyebabkan bencana tanah longsor dalam bentuk informasi spasial. Hasil yang didapat dapat digunakan sebagai upaya mitigasi untuk mengurangi dampak yang diakibatkan oleh bencana tanah longsor (Althuwaynee dkk., 2012).
Penelitian ini dilakukan di Kabupaten Bandung, Jawa Barat, untuk peta lokasi daerah penelitiannya dapat dilihat pada Gambar 1. berbatasan dengan Kabupaten Bandung Barat, Kota Bandung dan Kota Cimahi. Jawa Barat terbagi menjadi empat bagian zona fisiografi (Gambar 2), yaitu: zona Bogor, zona Bandung, dataran pantai Jakarta dan zona pegunungan selatan Jawa Barat. Kabupaten Bandung termasuk dalam Zona Bandung (Central

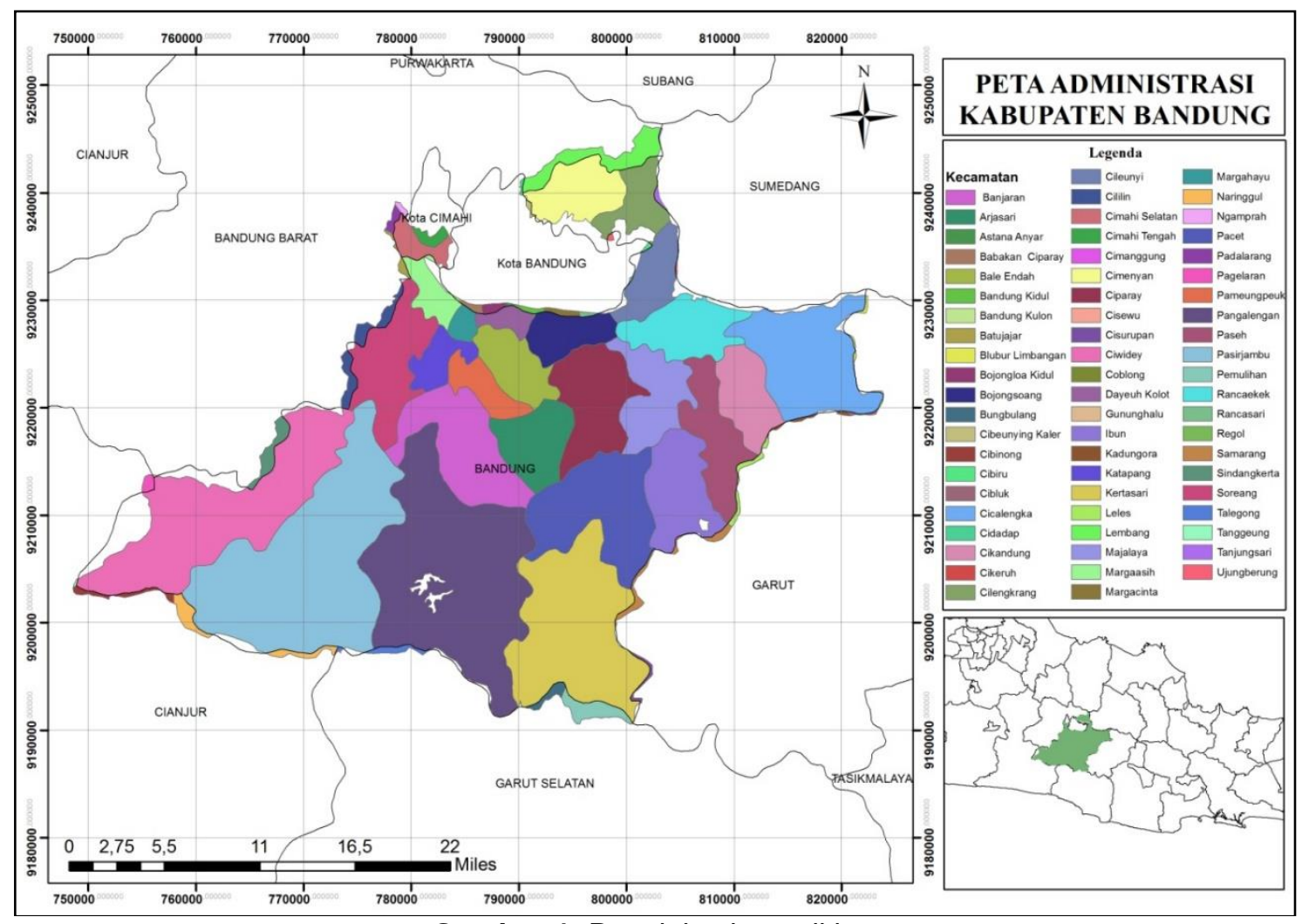

Gambar 1. Peta lokasi penelitian

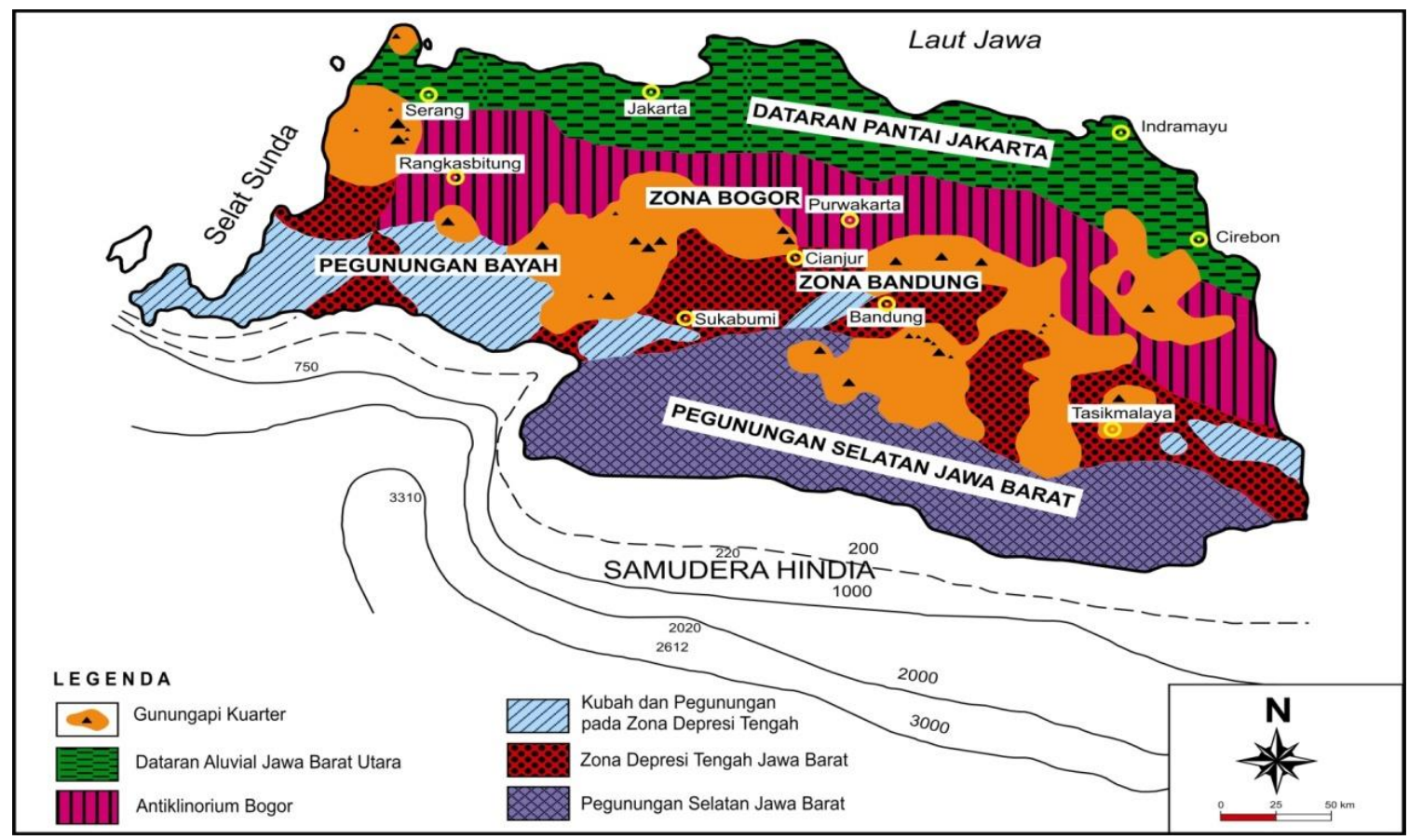

Gambar 2. Pembagian fisiografi daerah Jawa Barat 
Depression Zone of Java). Zona ini memiliki kenampakan depresi diantara gunung-gunung muda yang membentang membentuk lengkungan dari Pelabuhan Ratu mengikuti Lembah Cimandiri, melewati Kota Bandung, hingga ke Segara Anakan di muara Sungai Citanduy, dengan lebar zona antara $20-40 \mathrm{Km}$. Zona Bandung awalnya merupakan puncak geantiklin Jawa Barat yang kemudian runtuh setelah terjadinya uplift dan terisi endapan gunungapi muda. Dibeberapa tempat terdapat tinggian yang terbentuk dari endapan sedimen tua seperti Gunung Walat di Sukabumi dan Perbukitan Rajamandala di Kabupaten Bandung. Sebagian besar wilayah Kabupaten Bandung berupa pegunungan. Secara umum kondisi topografi Kabupaten Bandung terdiri ari dua unit topografi, yaitu daerah Lereng/ Punggung Bukit, Lembah/DAS.

Penginderaan jauh adalah pengukuran untuk memperoleh informasi tentang objek yang diperoleh tanpa kontak fisik dengan objek. Citra memiliki rentang panjang gelombang (wavelength band) sebagai karakter utamanya. Citra yang digunakan menggunakan sistem pasif yang memanfaatkan energi alami yaitu energi matahari untuk mendapatkan gambaran objek di permukaan bumi. Batas-batas wilayah Kabupaten Bandung, yaitu sebelah utara berbatasan dengan Kabupaten Bandung Barat, Kota Bandung, dan Kabupaten Sumedang; sebelah timur berbatasan dengan Kabupaten Sumedang dan Kabupaten Garut; sebelah selatan berbatasan dengan Kabupaten Garut dan Kabupaten Cianjur; dan sebelah barat.

Metode supervised classification digunakan untuk mengetahui penggunaan lahan di suatu area berdasarkan klasifikasi nilai piksel daerah yang diketahui jenis objek dan nilai spektralnya. Klasifikasi nilai piksel diperoleh dari data yang diambil langsung dari atau didapatkan dari data sekunder/statistik seperti peta, tabel, dan laporan.

Pemberian bobot setiap parameter berdasarkan sifat faktor itu sendiri, dimana faktor dinamis diberi bobot nilai lebih tinggi karena peristiwa tanah longsor disebabkan karena adanya perubahan gaya sebagai bentuk akibat dari perubahan faktor yang bersifat dinamis. Indikator faktor dinamis untuk curah hujan dan kemiringan lereng diberikan bobot yang lebih besar daripada infrastruktur. Hal karena perubahan massa batuan dan tanah lebih cepat berubah dalam jumlah besar akibat tingginya tekanan dari curah hujan (Damanik \& Restu, 2012; Purba dkk., 2014; Saputra dkk., 2015).

Perhitungan skor kumulatif pada penelitian ini, didasarkan pada KemenPU dengan rumus pembobotan yang digunakan adalah sebagai berikut (Yassar dkk., 2020; Taufik \& Firdaus, 2012):

Skor $=(20 \% \times$ faktor kelas curah hujan $)+(10 \% x$ faktor kelas struktur geologi $)+(15 \% \times$ faktor kelas jenis batuan $)+(20 \% \times$ faktor kelas penggunaan lahan $)+(25 \% \times$ faktor kelas lereng $)+(10 \%$ faktor infrastruktur $)$
Skor kumulatif yang diperoleh, nantinya dikelompokkan menjadi empat kelas, dengan kategori sebagai berikut:

1. Rendah $(\leq 2,5)$

2. Sedang $(\leq 2,6-\leq 3)$

3. Tinggi $(>3-\leq 3,6)$

Sangat Tinggi $(\geq 3,70$

\section{BAHAN DAN METODE PENELITIAN}

Metode yang dilakukan untuk mendukung penelitian ini adalah analisis data sekunder dan melakukan pembobotan data.

Data yang digunakan dalam penelitian ini yaitu:

1. Citra Satelit Landsat 8 path/row $121 / 65$ tahun 2020 (USGS).

2. DEM SRTM

3. Peta Digital Rupa Bumi Indonesia (RBI) wilayah Kabupaten Bandung skala $1: 25.000$.

4. Data Curah Hujan

5. Geologi Lembar Cianjur Skala 1:100.000

6. Geologi Lembar Sindangbarang dan Bandarwaru Skala 1:100.000

7. Geologi Lembar Bandung Skala 1:100.000

Geologi Lembar Garut dan Pemeungpeuk Skala 1:100.000 dapat dilihat alur kerja pada penelitian ini pada Gambar 3. Variabel dalam penelitian ini adalah:

a. Lokasi titik rawan longsor di Kabupaten Bandung.

b. Tingkat rawan longsor di Kabupaten Bandung dengan beberapa parameter yakni:

- Curah Hujan

- Kemiringan Lereng

- Struktur Geologi

- Penggunaan Lahan

- Jenis Batuan

- Infrastruktur

Analisis peta kerawanan tanah longsor dilakukan setelah peta-peta tematik parameter yaitu peta curah hujan, peta jenis tanah, peta geologi, peta kemiringan lereng wilayah tersebut telah diolah menjadi bentuk peta digital. Setiap jenis peta diklasifikasi berdasarkan skor serta diberi bobot kemudian dikelompokkan dan dianalisis. Pemetaan tersebut dilakukan dengan menggunakan software ArcGIS 10.3 sehingga menghasilkan peta intensitas curah hujan, peta sebaran jenis batuan, peta topografi atau kemiringan, peta sebaran struktur geologi, peta infrastruktur, peta administrasi, dan peta tutupan lahan. Data yang dihasilkan adalah berupa peta yang digunakan sebagai acuan penentuan daerah rawan bencana longsor di Kabupaten Bandung. Pada pembuatan peta perkiraan zona bencana tanah longsor, dilakukan terlebih dahulu proses analisis yang dilakukan berdasarkan parameter peta curah hujan, peta jenis batuan, peta struktur geologi, peta infrastruktur, peta tutupan lahan dan peta kemiringan lereng. Proses pemetaan yang dilakukan mengacu kepada 


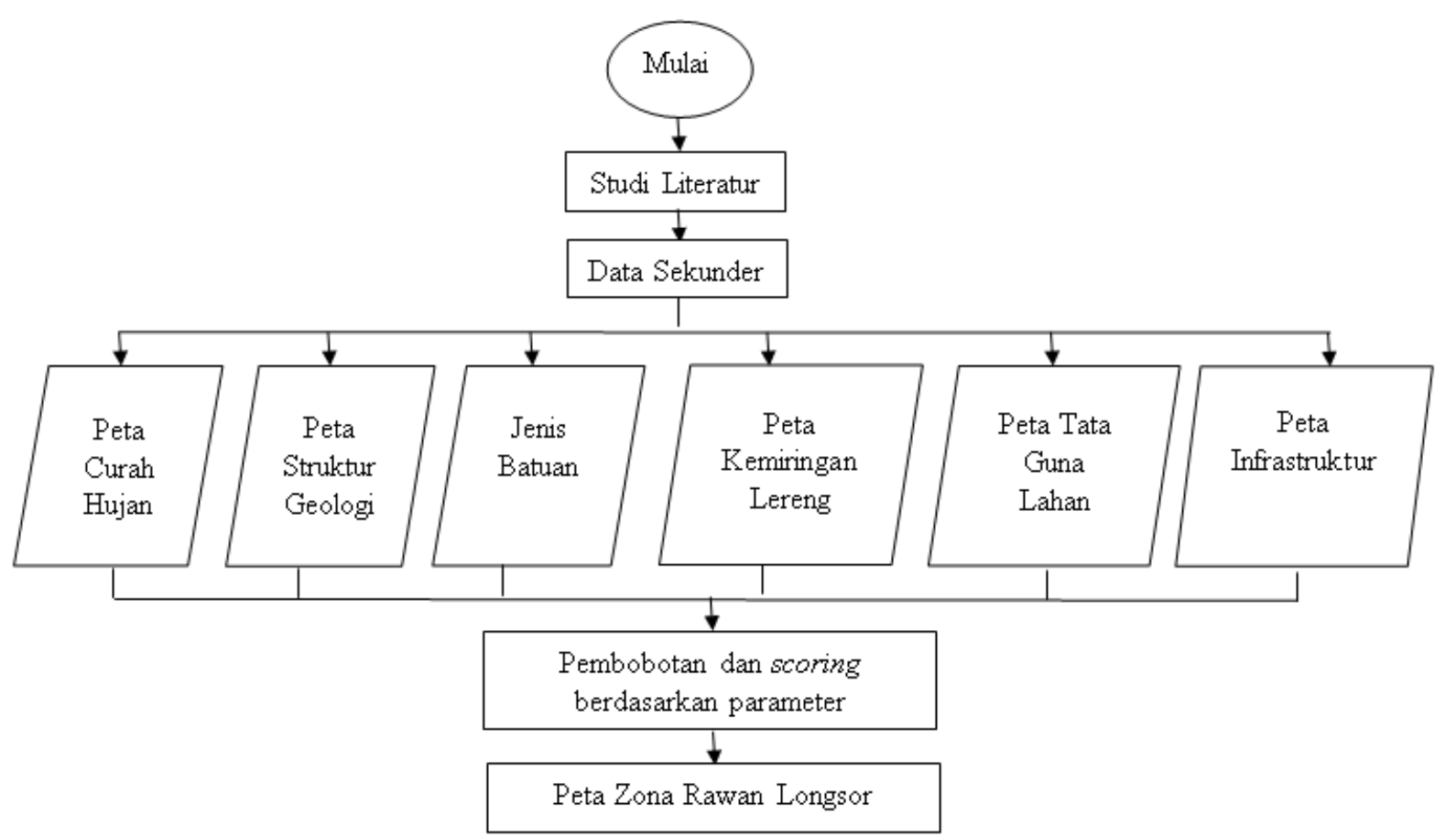

Gambar 3. Diagram alir penelitian

parameter KemenPU. Bobot tersebut didasarkan kepada pengaruh dari peta tersebut terhadap terjadinya bencana tanah longsor. Pada proses pemetaan dilakukan perkalian antara semua bobot dari parameter yang selanjutnya yang dibuat dijumlahkan dengan mempertimbangkan lokasi dan kesesuaian serta hubungannya dengan lokasi geografis wilayah tersebut (Tabel 1-6).

Tabel 1. Klasifikasi Curah Hujan (mm/tahun)

\begin{tabular}{ccc}
\hline Parameter & Bobot & Skor \\
\hline$<1000$ & & 1 \\
$1000-1499$ & $20 \%$ & 2 \\
$1500-2500$ & & 3 \\
$>2500$ & & 4 \\
\hline
\end{tabular}

Tabel 2. Klasifikasi Struktur Geologi

\begin{tabular}{|c|c|c|}
\hline Parameter & Bobot & Skor \\
\hline $\begin{array}{l}\text { Tidak ada struktur } \\
\text { Ada struktur }\end{array}$ & $10 \%$ & $\begin{array}{l}1 \\
4 \\
\end{array}$ \\
\hline \multicolumn{3}{|c|}{ Tabel 3. Klasifikasi Jenis Batuan } \\
\hline Parameter & Bobot & Skor \\
\hline Aluvial & & 1 \\
\hline Batuan & & 2 \\
\hline Berkapur/Metamorf & $15 \%$ & \\
\hline Batuan Sedimen & & 3 \\
\hline Batuan Vulkanik & & 4 \\
\hline
\end{tabular}

Tabel 4. Klasifikasi Tutupan Lahan

\begin{tabular}{ccc}
\hline Parameter & Bobot & Skor \\
\hline Non Tutupan Lahan & & 0 \\
Hutan Alam & & 1 \\
Perkebunan/Tegalan & $20 \%$ & 2 \\
Semak/Belukar/Rumput & & 3 \\
Sawah/Permukiman & & 4 \\
Gedung & & \\
\hline
\end{tabular}

Tabel 5. Klasifikasi Kemiringan Lereng

\begin{tabular}{ccc}
\hline Parameter & Bobot & Skor \\
\hline$<15 \%$ & & 1 \\
$15-24 \%$ & $25 \%$ & 2 \\
$25-44 \%$ & & 3 \\
$>45 \%$ & & 4 \\
\hline
\end{tabular}

Tabel 6. Infrastruktur

\begin{tabular}{ccc}
\hline Parameter & Bobot & Skor \\
\hline $\begin{array}{c}\text { Tidak ada jalan yang } \\
\text { memotong lereng } \\
\text { Jalan memotong lereng } \\
(\text { slope } 15-<25 \%)\end{array}$ & $10 \%$ & 1 \\
$\begin{array}{c}\text { Jalan memotong lereng } \\
(\text { slope } \geq 25 \%)\end{array}$ & & 4 \\
\hline
\end{tabular}

\section{HASIL DAN PEMBAHASAN}

Berdasarkan peta curah hujan Kabupaten Bandung tahun 2019, kabupaten Bandung memiliki intensitas curah hujan rendah dengan intensitas $1288 \mathrm{~mm} / \mathrm{tahun}$, dan intensitas curah hujan tinggi dengan $3.144 \mathrm{~mm} /$ tahun. Kisaran nilai curah hujan tersebut menunjukkan Kabupaten Bandung mempunyai tipe iklim sedang dengan curah hujan yang tertinggi terdapat di sebelah utara. Hujan dapat meningkatkan kadar air dalam tanah yang menyebabkan kondisi lereng menjadi berubah. Kenaikan kadar air akan memperlemah sifat fisik mekanik batuan. Air hujan menyebabkan perubahan sifat fisik batuan, yaitu menurunnya harga kohesi batuan, sehingga kekuatan geser batuan berkurang, sedangkan bobot masa batuan bertambah. Dengan meningkatnya bobot masa batuan maka kuat geser batuan akan menurun. 


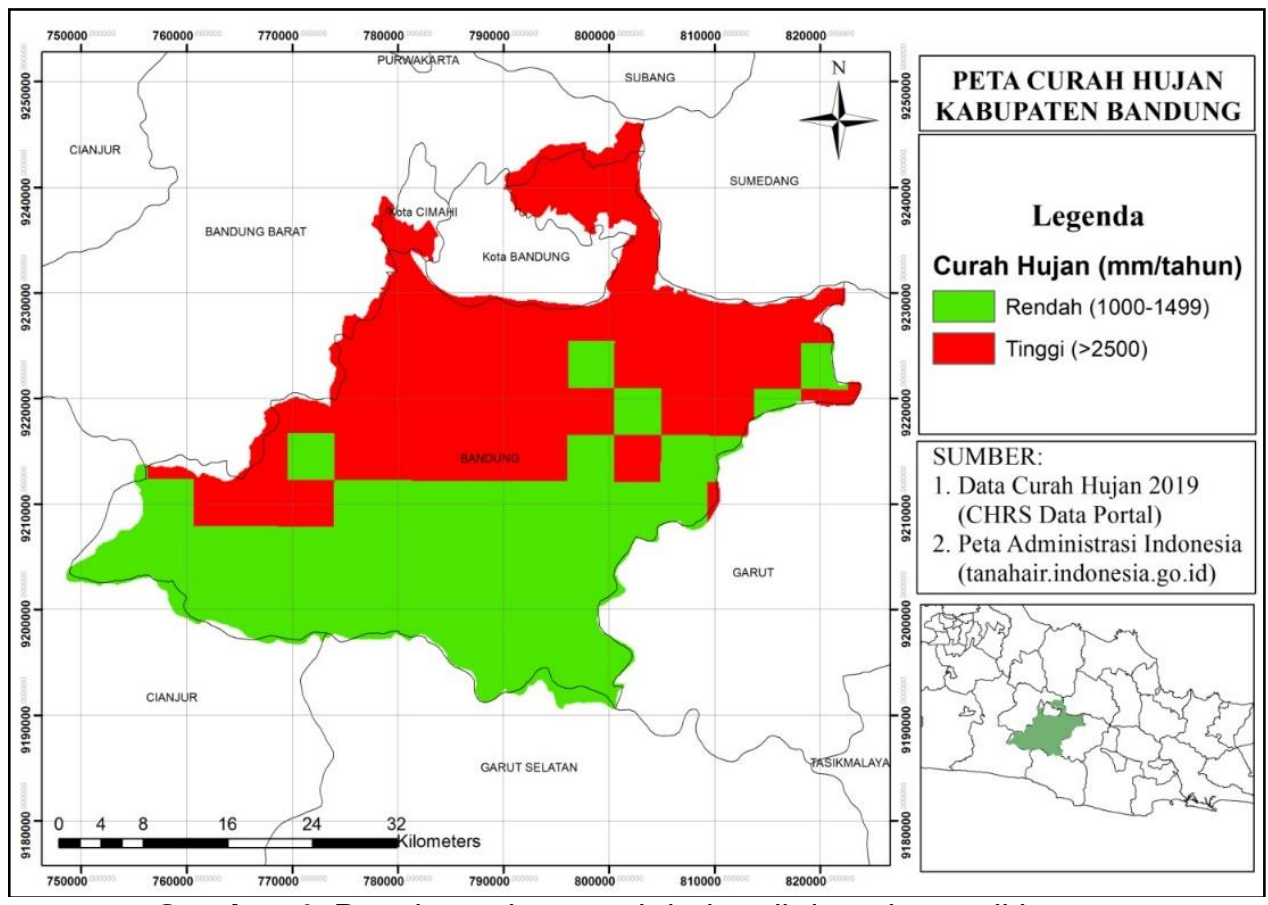

Gambar 4. Peta intensitas curah hujan di daerah penelitian

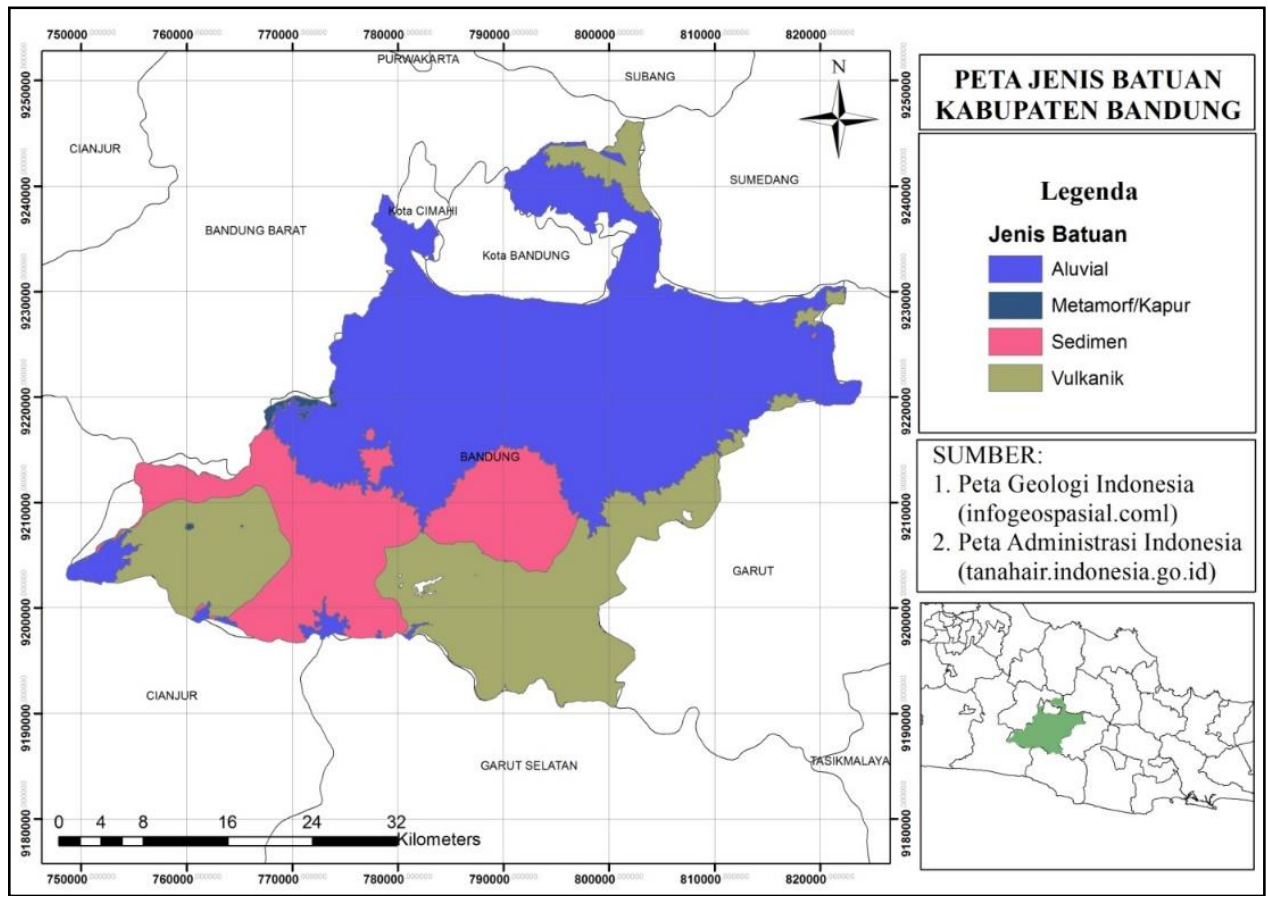

Gambar 5. Peta jenis batuan di daerah penelitian

Berdasarkan peta geologi, wilayah Kabupaten Bandung tersusun atas batuan vulkanik yang berasal dari gunung berapi, batuan sedimen, batuan metamorf, dan aluvial. Bila ditinjau dari sifat fisiografinya yang termasuk ke dalam zona Bandung yang didominasi oleh endapan gunung api muda dan endapan sedimen tua. Derajat kemiringan lereng di area penelitian diekstraksi dari pengolahan citra Aster GDEM-2. Berdasarkan data DEM, Kabupaten Bandung memiliki ketinggian berkisar antara 639-2602 mdpl. Data DEM tersebut diolah untuk mendapatkan kemiringan lereng (slope) dari nilai-nilai piksel di DEM dengan menggunakan operasi spasial sehingga menghasilkan kemiringan lereng seperti pada Gambar 6. Kelerengan merupakan salah satu faktor yang sangat penting dalam analisis longsor, karena kestabilan lereng berkurang pada morfologi berlereng terjal, sehingga menyebabkan besarnya gaya penggerak massa tanah/batuan penyusun lereng. Topografi atau kemiringan lereng yang terdapat pada Kabupaten Bandung terbagi menjadi empat zona klasifikasi yang berbeda. Zona pertama yaitu kemiringan kurang dari $<15 \%$ dan ini merupakan kemiringan lereng yang paling dominan, daerah yang memiliki kemiringan ini berada pada 
wilayah yang datar, kemudian kemiringan 15-24\% yang merupakan daerah yang berombak hingga bergelombang, lalu kemiringan 25-44\% merupakan daerah bergelombang sampai dengan berbukit. Selain itu, terdapat wilayah yang memiliki kemiringan $>45 \%$.

Kondisi topografi pada wilayah Kabupaten Bandung bagian selatan yang didominasi dengan tingkat kemiringan lereng mencapai $25 \%$ sampai di atas $45 \%$, menandakan bahwa pada wilayah ini berada pada dataran tinggi dengan kemiringan yang sangat curam sehingga diperlukan perhatian khusus untuk mencegah dan meminimalkan kemungkinan terjadinya bencana tanah longsor.
Citra Landsat 8 tahun 2020 dilakukan pemotongan atau subseting area studi dan supervised classification. Peta dasar yang digunakan sebagai acuan klasifikasi tutupan lahan adalah Peta RBI Kabupaten Bandung skala 1:25.000. Hasil klasifikasi tutupan lahan untuk tahun 2020 di Kabupaten Bandung dapat dilihat pada Gambar 7. Pada peta tutupan lahan di Gambar 7 nilai tutupan lahan yang sudah diklasifikasikan dibedakan menjadi 5 bagian. Pada bagian pertama yaitu bagian yang didominasi oleh sawah/ pemukiman/gedung. Kemudian bagian ke dua yaitu

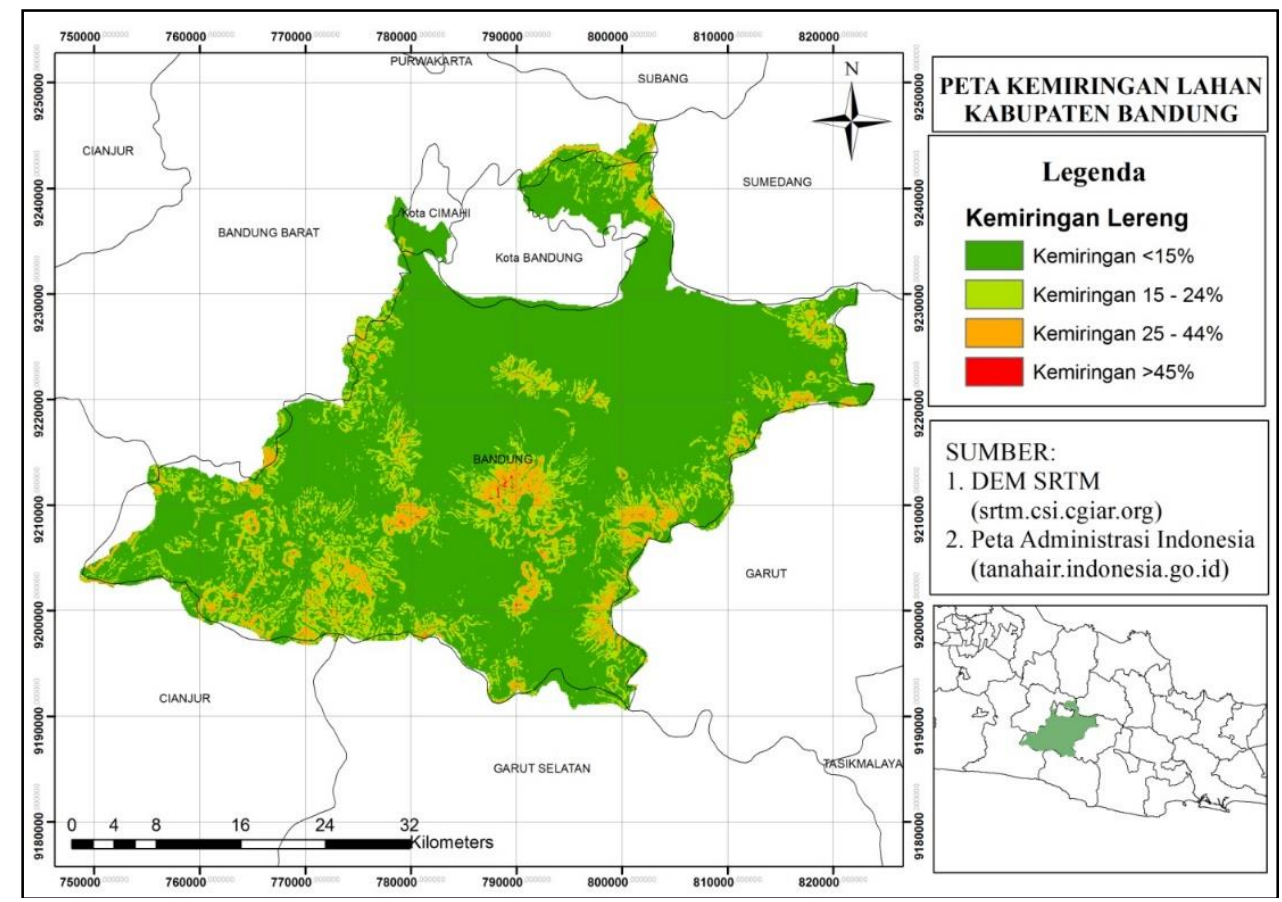

Gambar 6. Peta kemiringan lahan di daerah penelitian

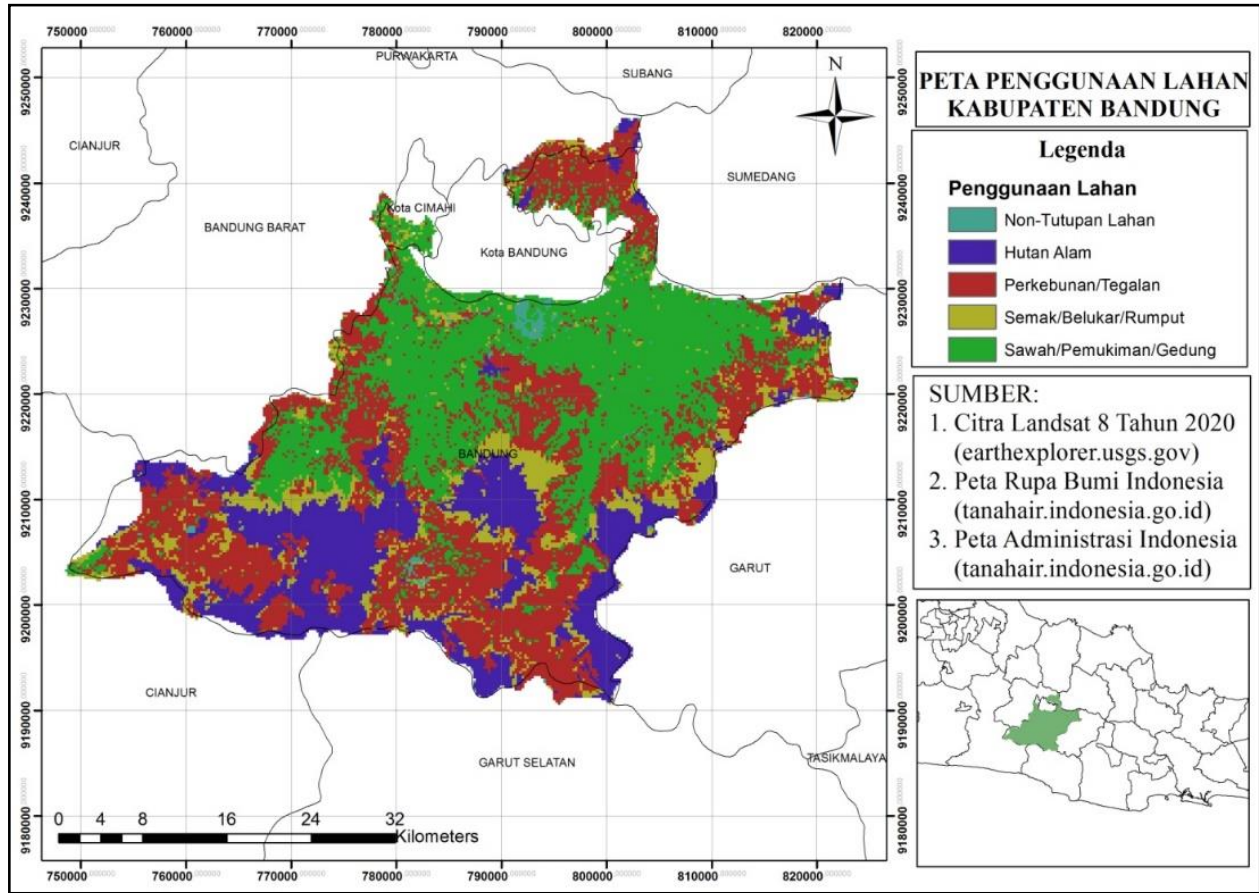

Gambar 7. Peta tutupan lahan di daerah penelitian 
bagian dominan tutupan lahannya berupa hutan alam yang diberi nilai sesuai skoring sesuai Tabel 1. Bagian ketiga yaitu bagian non-tutupan lahan. Bagian keempat berupa perkebunan/tegalan. Kemudian bagian yang terakhir yaitu bagian yaitu bagian yang memiliki tutupan lahan dominan berupa semak/belukar/ rumput. Pada daerah penelitian menunjukkan bahwa mayoritas lahan pada Kabupaten Bandung digunakan untuk pemukiman warga, gedung dan sawah. Beberapa pemukiman terletak di samping lereng yang mengalami longsor yang akan menambah beban pada tanah sehingga dapat menyebabkan tanah mudah longsor.

Faktor pengaruh struktur geologi yaitu berupa kekar dan bidang perlapisan batuan berpengaruh besar terhadap peristiwa tanah longsor. Batuan yang terkekarkan, merupakan zona lemah salah satu jalan masuknya air ke dalam tanah, akibatnya kekuatan geser batuan dalam menahan gerakan serta penjenuhan air dalam tanah/batuan dapat meningkatkan atau tekanan air pori dalam masa tanah/batuan, dan massa tersebut terdorong menjadi longsor. Wilayah selatan Kabupaten

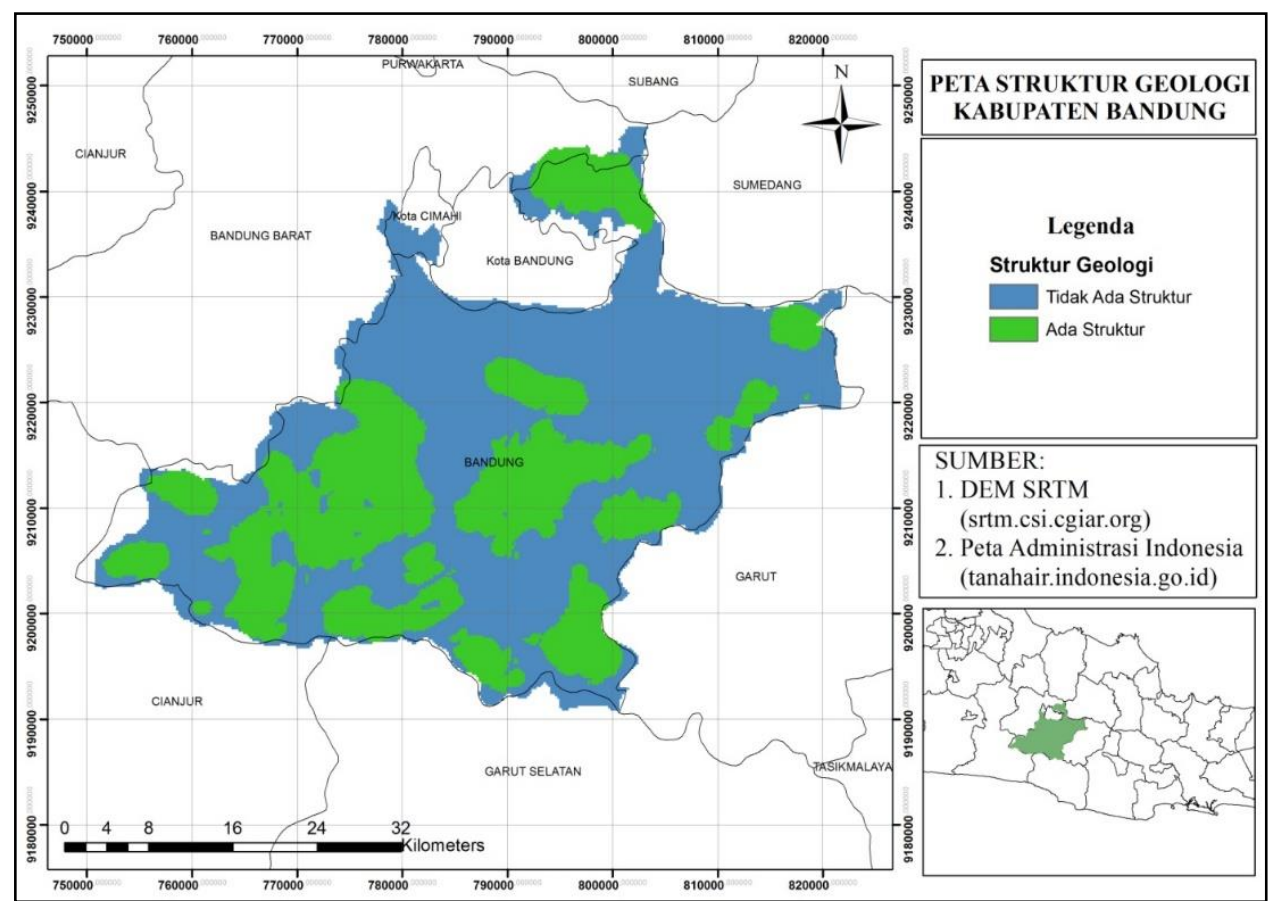

Gambar 8. Peta struktur geologi di daerah penelitian

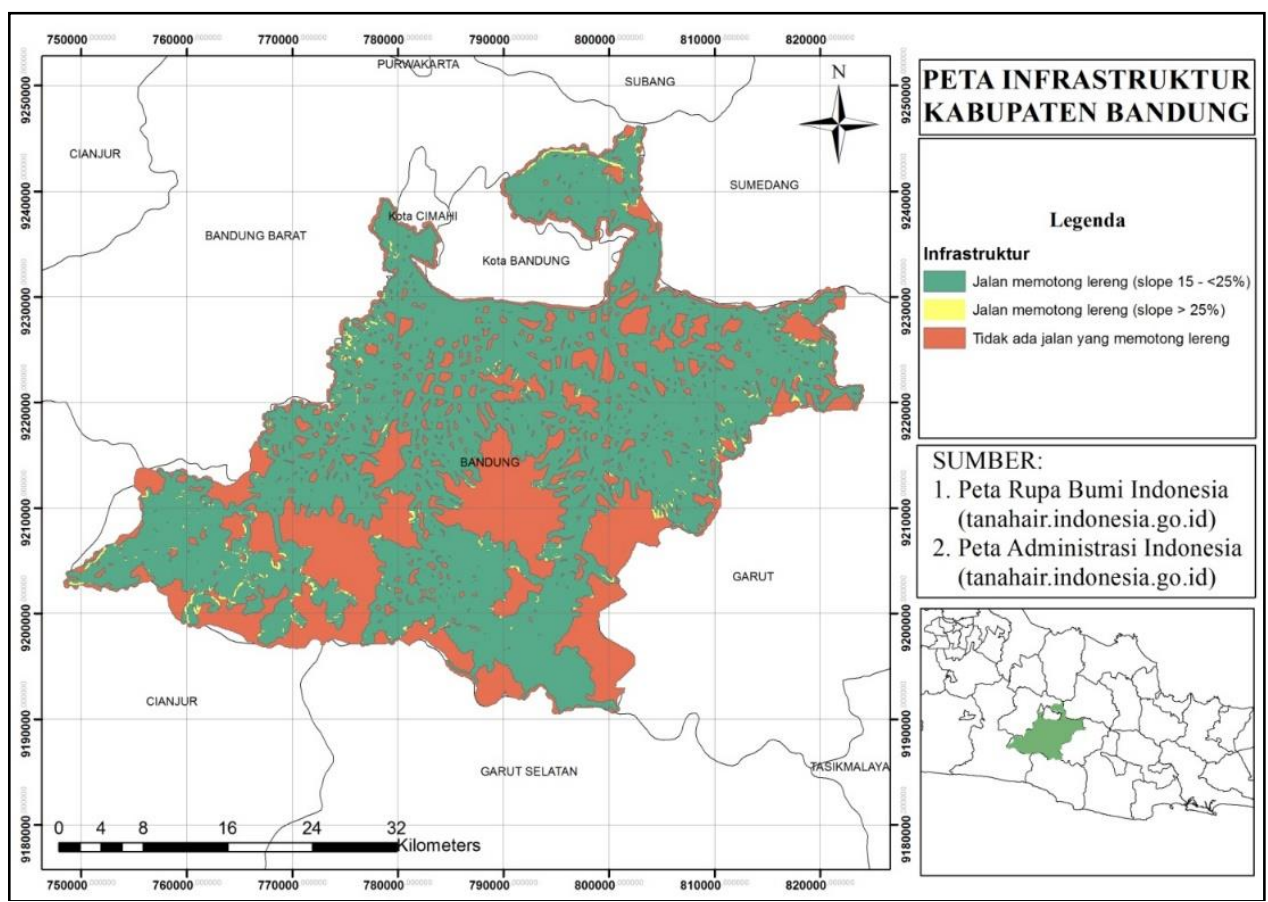

Gambar 9. Peta infrastruktur di daerah penelitian 
Bandung didominasi oleh keberadaan struktur geologi dapat dilihat pada Gambar 8. Bandung didominasi oleh keberadaan struktur geologi dapat dilihat pada Gambar 8.

Infrastruktur dapat berpengaruh terhadap longsor karena infrastruktur yang terbangun pada wilayah yang rentan terhadap longsor merupakan beban bagi lereng. Infrastruktur pada Kabupaten Bandung didominasi oleh bangunan jalan yang memotong lereng dengan slope 15 - <25\%. Infrastruktur tersebut, akan menjadi beban lereng yang akan mempengaruhi tingkat kestabilan lereng. Menurut Paimin dkk. (2012), infrastruktur merupakan salah satu faktor penyebab longsor dari aspek manajemen, dengan kategori sangat tinggi terhadap kerentanan longsor apabila ditemukan pembangunan infrastruktur jalan yang memotong lereng. Pemotongan tebing untuk alih fungsi lahan seperti pembangunan permukiman maupun sarana infrastruktur jalan tanpa memperhatikan prinsip konservasi, maka akan menimbulkan longsor (Abrauw, 2017; Khosiah dan Ariani, 2017).

Pendugaan kawasan bencana zona rawan bencana tanah longsor dilakukan dengan menggunakan model pendugaan yang bersumber pada penelitian yang dilakukan oleh kemenPU. Berdasarkan model tersebut parameter yang dibuat untuk menduga kawasan rawan longsor meliputi parameter jenis batuan, penutupan lahan, struktur geologi, curah hujan, infrastruktur serta kemiringan lahan. Semua parameter tersebut diklasifikasikan berdasarkan nilai skor kemudian diberikan bobot sesuai kontribusinya masing-masing dan kemudian data tersebut diolah. Berdasarkan hasil analisis lima parameter kerawanan longsor dengan menggunakan model Pendugaan Kerawanan Longsor KemenPU, didapatkan empat kriteria wilayah kerawanan longsor yaitu daerah dengan potensi rendah, sedang, tinggi, dan sangat tinggi.

Faktor topografi tinggi terutama di bagian selatan Kabupaten Bandung, material vulkanik yang kurang kompak, iklim tropis basah yang menyebabkan tingkat pelapukan sangat tinggi menyebabkan potensi longsor tinggi. Perkembangan pembangunan dan jumlah penduduk yang sangat pesat di Kabupaten Bandung menyebabkan perambahan permukiman penduduk ke daerah kritis yang rawan terhadap longsor. Penentuan tingkat kerawanan daerah longsor didasarkan dari hasil skor komulatif yang didapat dari keseluruhan parameter. Adapun persebaran daerah rawan longsor di Kabupaten Bandung dapat dilihat pada Gambar 10. Dalam peta tersebut menunjukan Kabupaten Bandung memiliki tingkat longsor yang didominasi tingkat sedang $(\leq 2,6-\leq 3)$ sampai tinggi $(>3-\leq 3,6)$ dengan kategori rawan. Persebaran daerah rawan longsor di Kabupaten Bandung dapat dilihat pada Gambar 10.

Berdasarkan pemodelan pendugaan kawasan rawan longsor yang dilakukan didapatkan bahwa intensitas curah hujan memiliki bobot yakni 25\%. Faktor jenis batuan memiliki bobot yakni 15\%, kemiringan lahan memiliki bobot terbesar yakni $25 \%$, penutupan lahan dengan bobot $20 \%$, faktor infrastruktur memiliki bobot yakni 10\% sedangkan faktor struktur geologi memiliki bobot $10 \%$. Berdasarkan penjelasan dan hasil analisis yang telah dilakukan dengan memperhatikan seluruh parameter tersebut maka akan didapatkan peta klasifikasi kerawanan longsor pada Kabupaten Bandung. Wilayah potensi risiko longsor tinggi berada di bagian tengah sampai selatan Kabupaten Bandung. Wilayah yang tidak rawan longsor tersebar di bagian utara yang merupakan dataran.

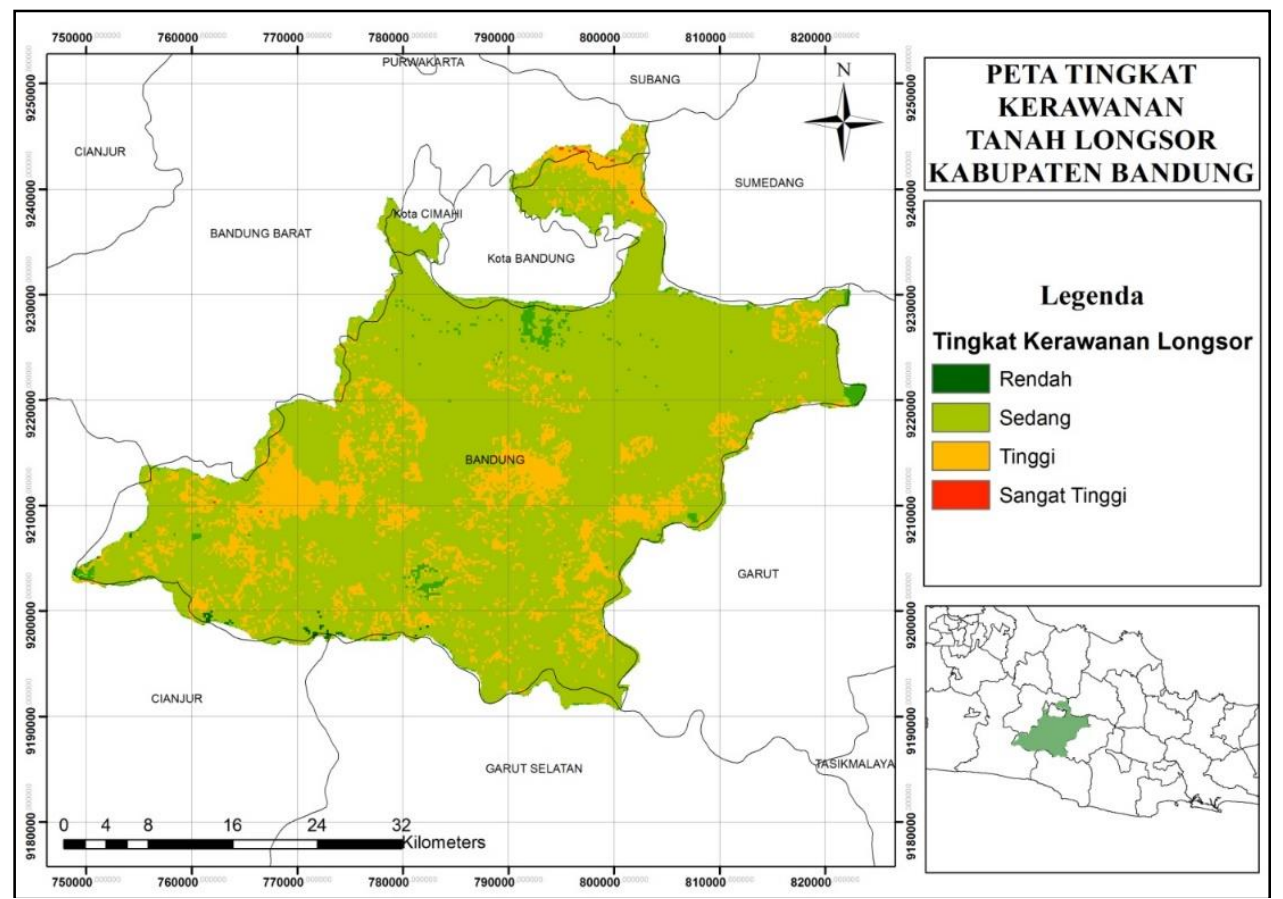

Gambar 10. Peta zona rawan tanah longsor hasil penelitian 


\section{KESIMPULAN}

Pemetaan zona rawan longsor dapat dihitung berdasarkan integrasi spasial dari parameterparameter yang mempengaruhi dan memicu longsor. Untuk mendapatkan parameter yang dibutuhkan dapat menggunakan metode penginderaan jauh yang didasarkan dari pengolahan citra, dalam penelitian ini menggunakan citra Landsat. Hasil pengolahan yang didapat menunjukkan zona daerah rawan longsor di Kabupaten Bandung didominasi kategori sedang sampai tinggi. Faktor topografi tinggi terutama di bagian selatan Kabupaten Bandung, material vulkanik yang kurang kompak, iklim tropis basah yang menyebabkan tingkat pelapukan sangat tinggi menyebabkan potensi longsor tinggi. Perkembangan pembangunan dan jumlah penduduk yang sangat pesat di Kabupaten Bandung menyebabkan perambahan permukiman penduduk ke daerah kritis yang rawan terhadap longsor. Wilayah potensi risiko longsor tinggi berada di bagian tengah sampai selatan Kabupaten Bandung. Wilayah yang tidak rawan longsor tersebar di bagian utara yang merupakan dataran.

\section{UCAPAN TERIMA KASIH}

Penulis mengucapkan terima kasih kepada Allah Subhanahu wa Ta'ala karena atas rahmatnya penulis dapat menyelesaikan penelitian ini. Penulis juga mengucapkan terima kasih kepada dosen pembimbing yang telah memberikan saran dan bimbingan dalam menyelesaikan penelitian ini. Serta pihak-pihak yang turut andil dalam proses penyelesaian penelitian ini.

\section{DAFTAR PUSTAKA}

Abrauw, R. D. (2017). Wilayah rawan longsor di Kota Jayapura. Jurnal Geografi Lingkungan Tropik, 1(1), 14-28.

Akgun, A., Kincal, C. \& Pradhan, B. (2012). Application of Remote Sensing Data and GIS for Landslide Risk Assessment as an Environmental Threat to Izmir City (West Turkey). Environ Monit Assess, 184, 54535470.

Althuwaynee, O. F., Pradhan, B. \& Lee, S. (2012). Application of an Evidential Belief Function Model in Landslide Susceptibility Mapping. Computers \& Geosciences, 44, 120-135.

Damanik, M. R. S., \& Restu, R. (2012). Pemetaan Tingkat Risiko Banjir dan Longsor Sumatera Utara Berbasis Sistem Informasi Geografis. Jurnal Geografi, 4(1), 29-42.

Erlansari, A., Susilo, B., \& Franky Hernoza. (2020). Optimalisasi Data Landsat 8 untuk Pemetaan Daerah Rawan Banjir dengan NDVI dan NDWI
(Studi Kasus: Kota Bengkulu). Jurnal Geofisika Eksplorasi Vol. 6/No. 1.

Khosiah \& Ariani, A. (2017). Tingkat Kerawanan Tanah Longsor Di Dusun Landungan Desa Guntur Macan Kecamatan Gunungsari Kabupaten Lombok Barat. JIME 3(1), 195-200.

Kurniawan, A. T. (2010). Visualisasi Risiko Bencana di Atas Peta: Studi Kasus: Penyusunan Peta Risiko di Provinsi DI. Yogyakarta. Fakultas Teknik Geodesi Universitas Gadjah Mada. Yogyakarta.

Paimin, Pratiwi, D., Santoso, H. \& Pusat Penelitian Dan Pengembangan Konservasi Dan Rehabilitasi. (2012). Sistem Perencanaan Pengelolaan Daerah Aliran Sungai. Pusat Penelitian dan Pengembangan Konservasi dan Rehabilitasi. Bogor, Indonesia: Kementerian Kehutanan, Badan Penelitian dan Pengembangan Kehutanan, Pusat Penelitian dan Pengembangan Konservasi dan Rehabilitasi.

Purba, J. O., Subiyanto, S., \& Sasmito, B. (2014). Pembuatan Peta Zona Rawan Tanah Longsor di Kota Semarang Dengan Melakukan Pembobotan Parameter. Jurnal Geodesi Undip, 3(2), 40-52.

Saputra, I. W. G. E., Ardhana, I. P. G., \& Adnyana, I. W. S. (2015). Analisis Risiko Bencana Tanah Longsor di Kecamatan Sukasada, Kabupaten Buleleng. ECOTROPHIC 10(1), 54-61.

Taufik, Q. \& Firdaus, D. (2012). Pemetaan Ancaman Bencana Tanah Longsor di Kabupaten Konawe. Jurnal Aplikasi Fisika, 8(1), 36-40.

Wafa, A. \& Astuti, E. S. (2016). Pemetaan Daerah Rawan Longsor Berbasis GIS di Kota Batu. Jurnal Informatika Polinema, 2(4), 144-146.

Wang, F., Xu, P., Wang, C., Wang, N., \& Jiang, N. (2017). Application of a GIS-Based Slope Unit Method for Landslide Susceptibility Mapping along the Longzi River, Southeastern Tibetan Plateau, China. ISPRS International Journal of Geo-Information, 6, 172.

Yassar, M. F., Nurul, M., Nadhifah, N., Sekarsari, N. F., Dewi, R., Buana, R., Fernandez, S. N., \& Rahmadhita, K. A. (2020). Penerapan Weighted Overlay Pada Pemetaan Tingkat Probabilitas Zona Rawan Longsor di Kabupaten Sumedang, Jawa Barat. Jurnal Geosains Dan Remote Sensing, 1(1), 1-10.

Zakaria, Z. (2010). Model Starlet, suatu Usulan untuk Mitigasi Bencana Longsor dengan Pendekatan Genetika Wilayah (Studi Kasus: Longsoran Citatah, Padalarang, Jawa). Indonesian Journal on Geoscience, 5(2), 93112. 